\title{
Effect of active vitamin D3 on VEGF- induced ADAM33 expression and proliferation in human airway smooth muscle cells: implications for asthma treatment
}

\author{
Sung-Ho Kim ${ }^{1 *}$, Qing-Mei Pei ${ }^{2}$, Ping Jiang ${ }^{1}$, Min Yang ${ }^{1}$, Xue-Jiao Qian ${ }^{1}$ and Jiang-Bo Liu ${ }^{1}$
}

\begin{abstract}
Background: Asthma is a chronic respiratory disease characterized by reversible airway obstruction with persistent airway inflammation and airway remodeling, which is associated with increased airway smooth muscle (ASM) mass. Vascular endothelial growth factor (VEGF) has been implicated in inflammatory and airway blood vessel remodeling in asthma. Recent evidence indicates that a deficiency of 1,25-dihydroxyvitamin D3 (1,25(OH)2D3) may influence asthma pathogenesis. A disintegrin and metalloproteinase (ADAM)33 has been identified as playing a role in the pathophysiology of asthma. ADAM33, which is expressed in ASM cells, is suggested to play a role in the function of these cells. Recent studies show that 1,25-(OH)2D3 exerts direct inhibitory effects on passively sensitized human ASM cells in vitro, including inhibition of ADAM33 expression and cell proliferation; however, the mechanism has not been fully understood.
\end{abstract}

Methods: In order to elucidate the precise mechanism underlying the effect of 1,25(OH)2D3 on VEGF-induced ADAM33 expression and ASM cell proliferation, we tested the effects of 1,25(OH)2D3 on cell cycle progression and evaluated the levels of phospho-VEGF receptor 2 (VEGFR2), phospho-extracellular signal-regulated kinase 1/2 (ERK1/2), and phospho-Akt in VEGF-stimulated ASM cells.

Results: We found that 1,25(OH)2D3 inhibited VEGF-induced ADAM33 expression and ASM cell proliferation, as well as cell cycle arrest. Additionally, VEGF-induced ADAM33 expression and ASM cell proliferation was suppressed via inhibition of ERK1/2 activity, but not that of Akt. Furthermore, 1,25(OH)2D3 treatment inhibited VEGF-induced activation of VEGFR2 as well as that of ERK and Akt in a concentration-dependent manner. 1,25(OH)2D3 also inhibited transforming growth factor (TGF)- $\beta$-induced VEGF secretion by ASM cells.

Conclusions: Collectively, our findings suggest that 1,25(OH)2D3 inhibits VEGF-induced ASM cell proliferation by suppressing VEGFR2 and ERK1/2 activation and downregulating ADAM33. Further studies of these mechanisms are needed to facilitate the development of treatments for smooth muscle hyperplasia-associated diseases of the airway such as asthma.

Keywords: Asthma, Vascular endothelial growth factor, ADAM33, 1,25-dihydroxyvitamin D3

\footnotetext{
* Correspondence: chenghao0726@hotmail.com

'Department of Respiration, Tianjin First Central Hospital, Fukanglu-24,

Nankaiqu, Tianjin 300192, China

Full list of author information is available at the end of the article
} 


\section{Background}

Asthma is a chronic respiratory disease characterized by reversible airway obstruction with persistent airway inflammation and airway remodeling. Airway remodeling and airway obstruction have several features in common such as airway smooth muscle (ASM) cell hyperplasia and hypertrophy, as well as increase in vascular permeability and angiogenesis $[1,2]$, both of which have been the target for numerous therapeutic regimens.

Recently, several growth factors and cytokines secreted by inflammatory cells have been implicated in ASM cell growth and division. Among these, Vascular endothelial growth factor (VEGF)-A (hereafter called VEGF) has been implicated in asthma-related inflammation and remodeling $[3,4]$.

Various cytokines, cellular elements, oxidative stress, and protease/antiprotease levels affect lung fibroproliferation, remodeling, and function, which may be influenced by vitamin D levels [5]. Moreover, previous studies have suggested the active involvement of VEGF in the pathogenesis of asthma, which may be mediated by 1,25-dihydroxycholecalciferol [1,25(OH)2 D3], the active form of vitamin D. In addition, 1,25(OH)2D3 has also been shown to inhibit the proliferation of airway smooth muscle cells [6]. A disintegrin and metalloproteinase (ADAM)33, a recently discovered ADAM family member, has been found to play a role in the pathophysiology of asthma [7]. Similar to other protease-type ADAM members, the active site sequence of ADAM33 lies in the metalloprotease domain, implying that this protein promotes the processing of growth factors, various adhesion molecules, cytokines, and cytokine receptors [8]. ADAM33 is preferentially expressed in smooth muscle cells, fibroblasts, and myofibroblasts, but not in $\mathrm{T}$ cells, epithelial cells, or inflammatory cells [9]. ADAM33 has been linked to allergic airway inflammation; however, its role in the pathophysiology of asthma remains to be proven. Recent studies show that 1,25- $(\mathrm{OH}) 2 \mathrm{D} 3$ exerts direct inhibitory effects on passively sensitized HASMCs in vitro, including inhibition of cell proliferation and expression of ADAM33 [10, 11]. However, the mechanisms underlying 1,25-(OH)2D3-induced inhibitory effects on ASM cell proliferation and expression of ADAM33 remain poorly defined.

Therefore, in the present study, we aimed to investigate the mechanisms underlying the inhibitory effects of 1,25-(OH)2D3 on VEGF-induced ADAM33 expression and ASM cell proliferation. Evaluation of cell proliferation by bromodeoxyuridine (BrdU) labeling has been described in several cell types and species. The key principle of this method is that BrdU is incorporated as a thymidine analog into nuclear DNA, thus acting as a marker that can be tracked with antibodies [12].

\section{Methods}

\section{Antibodies and reagents}

Antibodies against phospho-ERK1/2 ( $\left.\mathrm{Thr}^{202} / \mathrm{Tyr}^{204}\right)$, phospho-Akt $\left(\mathrm{Ser}^{473}\right)$, phospho-VEGFR2 ( $\mathrm{Tyr}^{1175}$ ), ERK1/ 2, Akt, and VEGFR2 were purchased from cell signaling technology (Danvers, MA). Antibody against ADAM33 and $\beta$-actin was obtained from Santa Cruz Biotechnology (Santa Cruz, CA). The secondary antibodies were obtained from (Jackson Immunoresearch, West Grove, PA). 1,25-(OH)2D3, TGF- $\beta 1$, and VEGF were purchased from Sigma-Aldrich (St. Louis, MO). SU1498 was from CalBiochem (La Jolla, CA). PI3-K inhibitor LY294002, and the MAPK/ERK1/2 inhibitor U0126 were obtained from CalBiochem (La Jolla, CA).

\section{Cell culture}

Human ASM cells were obtained from ScienCell Research laboratories. Cells were cultured in six-well plates in Smooth Muscle Cell Medium (SMCM) containing $10 \% \mathrm{FBS}$ and were maintained at $37{ }^{\circ} \mathrm{C}$ and $5 \% \mathrm{CO}_{2}$ as previously described [13]. Cells from passage 3-6 maintained their SMC phenotype and were used in all experiments. ASM cells were characterized by smooth muscle cell markers including smooth muscle $\alpha$-actin and smooth muscle heavy chain using immunofluorescence. In inhibition experiments, inhibitors of signal transduction pathways were added for $2 \mathrm{~h}$ before the addition of VEGF. All inhibitors were dissolved in dimethyl sulfoxide (DMSO; final concentration of $0.1 \%, \mathrm{vol} / \mathrm{vol}$ ) and added to the medium. Vehicle controls contained the same amount of DMSO.

\section{Real-time reverse transcriptase-PCR}

Total RNA was isolated from ASM cells using a TRIzol regent (Invitrogen) after exposure to VEGF or 1,25$(\mathrm{OH}) 2 \mathrm{D} 3$. Total RNA $(2 \mu \mathrm{g})$ was reverse transcribed using the oligo (dT) primer and MMLV reverse transcriptase (Promega, Madison, WI) at $42{ }^{\circ} \mathrm{C}$ for $90 \mathrm{~min}$. Real-time PCR was performed using an ABI Prism 7500 instrument according to the manufacturer's instructions (Applied Biosystems, Foster City, CA). The following primer pairs were used: ADAM33, forward 5'- CAGG AATGCCAGCTATTATC -3' and reverse, 5'-GTTTG GTGTGGTTCAAGTTT-3'; and GAPDH, forward 5'GGCCAAAAGGGTCATCA TC -3' and reverse, 5'GTGATGGCATGGACTGTGG-3'. After an initial hot start for $10 \mathrm{~min}$, amplification was performed for 40 cycles consisting of denaturation for $10 \mathrm{~s}$ at $94{ }^{\circ} \mathrm{C}$, annealing for $30 \mathrm{~s}$ at $56{ }^{\circ} \mathrm{C}$, and extension for $40 \mathrm{~s}$ at $72{ }^{\circ} \mathrm{C}$. The amplification kinetics was recorded as sigmoid progress curves for which fluorescence was plotted against the number of amplification cycles. The threshold cycle number (CT) was used to define the initial amount of each template. The CT was the first cycle for which a 
detectable fluorescent signal was observed. The mRNA expression levels were determined and compared with the GAPDH standard.

\section{BrdU incorporation assay}

ASM cells were seeded in 96-well plates and treated with various drugs as indicated in each experiment for indicated times. At the end of treatment, BrdU incorporation was assayed by incubating the cells with BrdU for 0.5-1 h using a BrdU Cell Proliferation Assay Kit (Calbiochem, San Diego, CA) according to the manufacturer's instructions.

\section{Establishment of ADAM33 overexpressing cell lines}

To generate ADAM33 overexpressing vectors, the ADAM33-coding sequences were obtained by reverse transcription PCR and cloned into pMXs-based retroviral plasmid (Addgene). Human ASM cells were infected as described [14], to establish ADAM33 overexpressing ASM cells (ASM cells-ADAM33), and ASM cells infected with retrovirus containing blank pMXs vector (ASM cellsvector) were used as the control group.

\section{Cell cycle analysis}

ASM cells were cultured in the complete medium with 1,25- $(\mathrm{OH}) 2 \mathrm{D} 3$ for $2 \mathrm{~h}$ before treated or not with $50 \mathrm{ng} / \mathrm{ml}$ of VEGF for $48 \mathrm{~h}$. All the cells were collected, and $1 \times 10^{6}$ cells were centrifuged, resuspended in ice-cold $70 \%$ ethanol and stored at $-20{ }^{\circ} \mathrm{C}$ until further analysis. Washed cells were stained by $0.1 \%$ Triton X-100 in $0.01 \mathrm{M}$ phosphate-buffered saline ( $\mathrm{pH} 7.2)$ with $50 \mu \mathrm{g} / \mathrm{ml}$ propidium iodide (Sigma-Aldrich) and $1 \mathrm{mg} / \mathrm{ml}$ RNase A (Invitrogen), and incubated at $37^{\circ} \mathrm{C}$ for $30 \mathrm{~min}$ in the dark. Samples of the cells were then analyzed for their DNA content using FACScan flow cytometry (Beckman, Miami, FL), and cell cycle phase distributions were analyzed by the Cell Quest acquisition software (BD Biosciences, Franklin Lanes, NJ). All experiments were performed in duplicate and repeated twice.

\section{Western blot analysis}

The cell extracts were separated by $10 \%$ sodium dodecyl sulphate-polyacrylamide gel electrophoresis (SDS-PAGE) and transferred onto a nitrocellulose membrane. The membranes were blocked in blocking solution [5\% non-fat dried milk in phosphate buffered saline (PBS)] for $2 \mathrm{~h}$ at room temperature and then probed with anti-ADAM33, anti-VEGFR2, anti-P-VEGFR2, anti-P-ERK1/2, anti-ERK1/ 2 , anti-P-Akt, anti-Akt, and anti- $\beta$-actin for $1 \mathrm{~h}$ at room temperature. After washing three times in phosphatebuffered saline (PBS) containing $0 \cdot 1 \%$ Tween-20 (PBS-T), the membranes were incubated with secondary antibodies for $1 \mathrm{~h}$ at room temperature. After washing an additional three times in PBS-T, the membranes were developed using an electrochemiluminescence (ECL) solution (Pierce, Rockford, IL, USA) and exposed to Kodak X-ray film.

\section{Transfection of small interfering RNA (siRNA)}

ADAM33 siRNAs were purchased from Santa Cruz Biotechnology (Santa Cruz, CA). ADAM33 was transfected into ASM cells, ASM cells-ADAM33, and ASM cellsvector according to a siRNA transfection protocol provided by Santa Cruz Biotechnology. Briefly, after culturing ASM cells in antibiotic-free SMCM at $37{ }^{\circ} \mathrm{C}$ in a humidified atmosphere of $5 \% \mathrm{CO}_{2}$ for $24 \mathrm{~h}$, the siRNA duplex solution, which was diluted in siRNA transfection medium (Santa Cruz Biotechnology), was added to the ASM cells. After transfection for $24 \mathrm{~h}$, the medium was replaced with normal SMCM, and ASM cells were treated with VEGF. Scrambled siRNA, purchased from Santa Cruz Biotechnology, was transfected to ASM cells as a negative standard.

\section{Measurement of VEGF secretion}

ASM cells were incubated with indicated doses of 1,25$(\mathrm{OH}) 2 \mathrm{D} 3$ for $48 \mathrm{~h}$ after stimulation with TGF- $\beta 1$ for $30 \mathrm{~min}$, and then the VEGF concentration in each supernatant was quantified using an ELISA kit for human VEGF (Invitrogen, Camarillo, CA) according to the manufacturer's instructions.

\section{Statistical analysis}

All results are expressed as the mean \pm SEM. The statistical evaluation of the results was performed by an independent $t$-test and an ANOVA with a Tukey post-hoc test. The results were significant with a value of $p<0.05$.

\section{Results}

1,25-(OH)2D3 inhibits VEGF-induced ADAM33 expression in ASM cells

In order to evaluate the direct effect of 1,25- $(\mathrm{OH}) 2 \mathrm{D} 3$ on the VEGF-induced expression of ADAM33 in ASM cells, we performed real-time PCR. ASM cells were treated with various doses of $1,25-(\mathrm{OH}) 2 \mathrm{D} 3$, and at various times after treatment or not with $50 \mathrm{ng} / \mathrm{ml}$ of VEGF for $30 \mathrm{~min}$; as a result, VEGF-induced ADAM33 expression was downregulated in a dose- and time-dependent manner (Fig. 1a, b). In addition, we performed western blot analysis to evaluate whether 1,25- $(\mathrm{OH}) 2 \mathrm{D} 3$ additionally regulates VEGF-induced ADAM33 protein expression in ASM cells. Interestingly, 1,25- $(\mathrm{OH}) 2 \mathrm{D} 3$ also downregulated VEGF-induced ADAM33 protein expression in ASM cells in a dose- and time-dependent manner (Fig. 1c, d).We did not observe any VEGF- and/ or 1,25-(OH)2D3-induced cytotoxicity under the present experimental conditions (data not shown). 


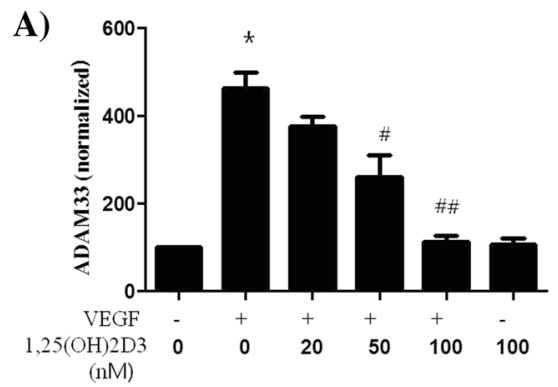

C)

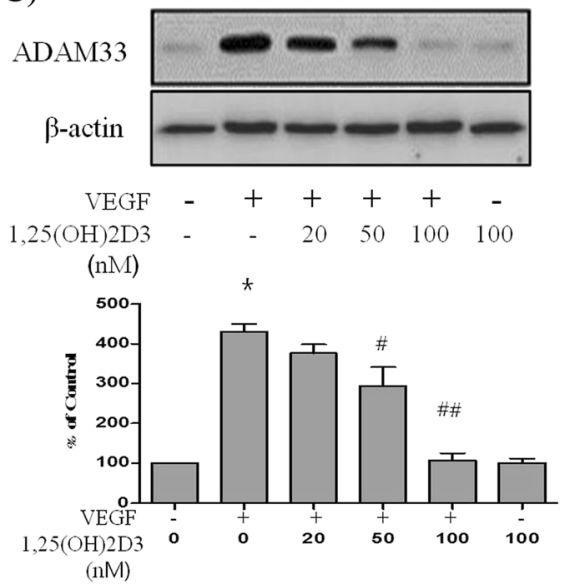

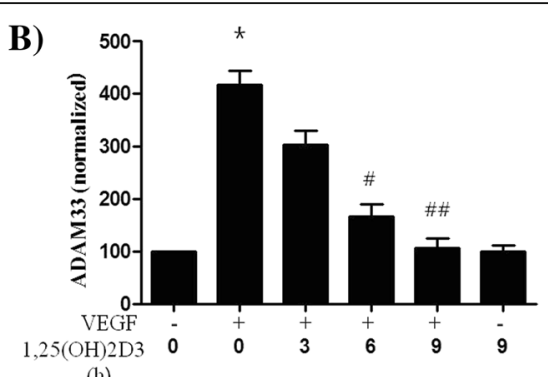

(h)

D)

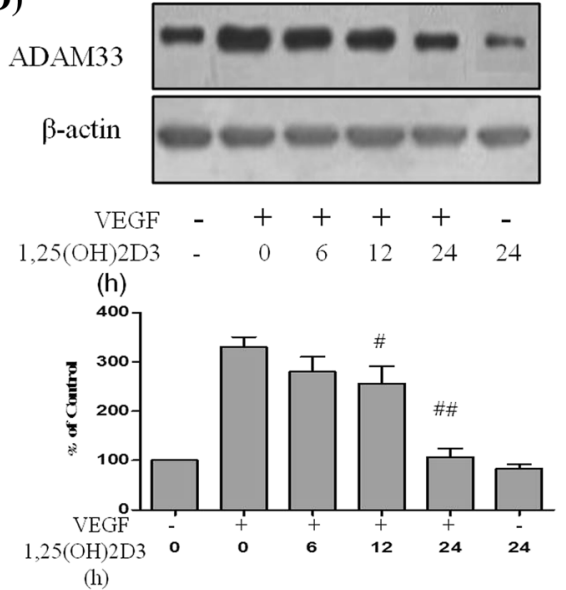

Fig. 1 1,25(OH)2D3 inhibits VEGF-induced ADAM33 expression at both mRNA and protein level. ASM cells were incubated with various doses of 1,25(OH)2D3 for $9 \mathrm{~h}$ before treatment or not with $50 \mathrm{ng} / \mathrm{ml}$ of VEGF for $30 \mathrm{~min}$, and then real-time PCR performed (a). ASM cells were incubated at indicated times of $100 \mathrm{nM}$ of 1,25(OH)2D3, and then real-time PCR performed (b). The values are normalized relative to the GAPDH standard. ASM cells were incubated with various doses of 1,25(OH)2D3 for $24 \mathrm{~h}$ before treatment or not with $50 \mathrm{ng} / \mathrm{ml}$ of VEGF for $30 \mathrm{~min}$, and then western blotting analysis for ADAM33 was performed (c). ASM cells were incubated at indicated times of $100 \mathrm{nM}$ of 1,25(OH)2D3 before treatment or not with $50 \mathrm{ng} / \mathrm{ml}$ of VEGF for $30 \mathrm{~min}$, and then western blotting analysis for ADAM33 was performed (d). $\beta$-actin was used as a loading control. All data are representative of three independent experiments. Values represent the means $\pm \mathrm{SEM}$. ${ }^{*} P<0.05 \mathrm{vs}$. control, ${ }^{\#} P<0.05$, \#\# $P<0.005 \mathrm{vs}$. VEGF alone

1,25-(OH)2D3 inhibits VEGF-induced ASM cell proliferation by downregulating ADAM33 expression

It has been reported that VEGF-D-enhanced ADAM33 plays an important role in tumor cell proliferation in the gastric cancer cell line SNU-601. We initially tested the effect of 1,25-(OH)2D3 on the VEGF-induced proliferation of ASM cells. When ASM cells were treated with various doses of 1,25-(OH)2D3, and at different times after treatment or not with $50 \mathrm{ng} / \mathrm{ml}$ of VEGF for $30 \mathrm{~min}, 1,25-(\mathrm{OH}) 2 \mathrm{D} 3$ inhibited VEGF-enhanced BrdU incorporation in a dose- and time-dependent manner in ASM cells (Fig. 2a, b).

Next, to elucidate the effect of ADAM33 on the proliferation of ASM cells, we constructed an ADAM33 siRNA transfection reagent. As shown in Fig. 2c and d, we confirmed ADAM33 gene silencing at the mRNA and protein level. To further confirm the silencing effect of ADAM33 siRNA in ASM cells, a rescue experiment was performed with ADAM33 siRNA in ASM cells-ADAM33. Herein, western blot analysis was also performed to assess ADAM33 expression in ASM cells-ADAM33 treated with ADAM33 siRNA (ASM-ADAM33 siRNA). The result of western blot analysis indicated that the expression of ADAM33 was significantly downregulated in ASMADAM33 siRNA compared with ASM cells-ADAM33 and ASM cells-ADAM33 treated with nontargeting control siRNA (ASM-control siRNA) (Fig. 2e). These results indicated that the ADAM33 siRNA was effective in our study.

The cell proliferation ability was further evaluated. As expected, When ASM cells-ADAM33 cells were transfected with ADAM33 siRNA or control siRNA for $48 \mathrm{~h}$ in the presence of $50 \mathrm{ng} / \mathrm{ml}$ VEGF and $100 \mathrm{nM} 1,25$ $(\mathrm{OH}) 2 \mathrm{D} 3, \mathrm{BrdU}$ incorporation was decreased in ADAM33 siRNA-transfected cells compared with negative control siRNA-transfected cells (Fig. 2f). These data indicate that 1,25-(OH)2D3 inhibits VEGF-induced proliferation of ASM cells by downregulating ADAM33 expression.

\section{1,25-(OH)2D3 induces G1-phase cell-cycle arrest in VEGF-induced ASM cell proliferation}

Flow cytometry analysis was performed to assess whether the anti-proliferative effect of 1,25-(OH)2D3 was due to cell-cycle arrest in a specific phase. As shown in Fig. 3, VEGF treatment significantly increased the 

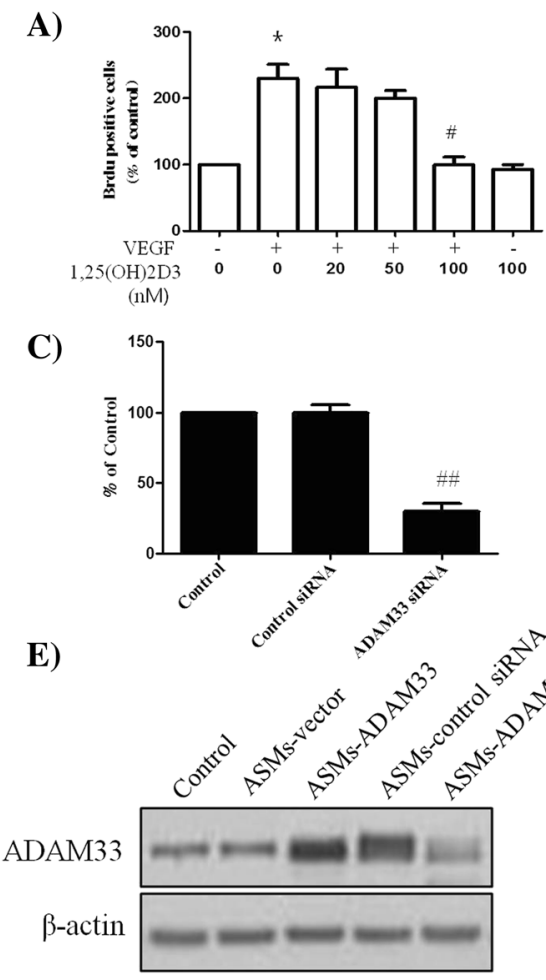

Fig. 2 1,25(OH)2D3 inhibits cell proliferation by down-regulation of ADAM33 expression. ASM cells were incubated with various doses of 1,25(OH)2D3 for $48 \mathrm{~h}$ before treatment or not with $50 \mathrm{ng} / \mathrm{ml}$ of VEGF for $30 \mathrm{~min}$, and then cell proliferation was determined by BrdU incorporation (a). ASM cells were incubated at indicated times of $100 \mathrm{nM}$ of 1,25(OH)2D3 before treatment or not with $50 \mathrm{ng} / \mathrm{ml}$ of VEGF for 30 min, and then cell proliferation was determined by BrdU incorporation (b). ASM cells were transfected with negative siRNA or ADAM33 siRNA, and then real-time PCR performed. The values are normalized relative to the GAPDH standard (c). ASM cells (d) and ASM cells-ADAM33 (e) were transfected with negative siRNA or ADAM33 siRNA, and then western blotting analysis for ADAM33 was performed. $\beta$-actin was used as a loading control. ASM cells-ADAM33 were transfected with negative siRNA or ADAM33 siRNA in the presence of VEGF $(50 \mathrm{ng} / \mathrm{ml})$ and 1,25-(OH)2D3 (100 nM) for $48 \mathrm{~h}$, and then cell proliferation was determined by BrdU incorporation (f). All experiments were done at least three times. Values represent the means \pm SEM. ${ }^{*} P<0.05$ vs. control or ASMs-vector; $\# P<0.05$ vs. VEGF alone or control siRNA or ASMs-control siRNA

proportion of ASM cells in the $\mathrm{S}$ and $\mathrm{G} 2 / \mathrm{M}$ phases of the cell cycle, with a concomitant decrease in the proportion in G1 phase relative to control cells. However, 1,25- $(\mathrm{OH}) 2 \mathrm{D} 3$ treatment in the presence or absence of VEGF markedly reduced the percentage of cells in the $S$ and $\mathrm{G} 2 / \mathrm{M}$ phases, resulting in a significant accumulation of cells in G1 phase, relative to VEGF-stimulated ASM cells. Cell proliferation was only slightly affected by $1,25-(\mathrm{OH}) 2 \mathrm{D} 3$ alone compared with the group without VEGF challenge.

\section{1,25-(OH)2D3 inhibits VEGF-induced ADAM33 expression and ASM cell proliferation through inactivation of VEGFR2 (KDR/Flk1)}

Several studies have reported that VEGF-induced cell proliferation is mediated by the interaction of VEGF with VEGFR2 (also known as KDR or FLK1). In order to determine whether blocking the VEGF-VEGFR2 interaction prevents VEGF-mediated ADAM33 upregulation and ASM cell proliferation, we used SU1498, an inhibitor of the tyrosine kinase activity of VEGFR2. SU1498 blocks the interaction of VEGF with VEGFR2 but not with VEGFR1 (FLT1). As shown in Fig. 4a, VEGF-increased ADAM33 expression was inhibited by SU1498 in a dose-dependent manner. In addition, SU1498 blocked VEGF-induced BrdU incorporation in ASM cells (Fig. 4b). Finally, we performed western blot analysis to evaluate whether 1,25-(OH)2D3 also regulates VEGF-induced VEGFR2 activation in ASM cells. Interestingly, 1,25-(OH)2D3 also downregulated VEGF-induced VEGFR2 activation in ASM cells in a dose-dependent manner. These data indicate that 1,25-(OH)2D3 inhibits VEGF-induced ADAM33 expression and cell proliferation by suppression of the VEGF/VEGFR2 interaction.

\section{1,25-(OH)2D3-mediated inhibition of VEGF-induced ADAM33 expression and cellular proliferation involves the MAPK/ERK1/2 pathway}

The majority of in vitro reports suggest that PI3-K and ERK1/2 activation represents the major signal transduction 


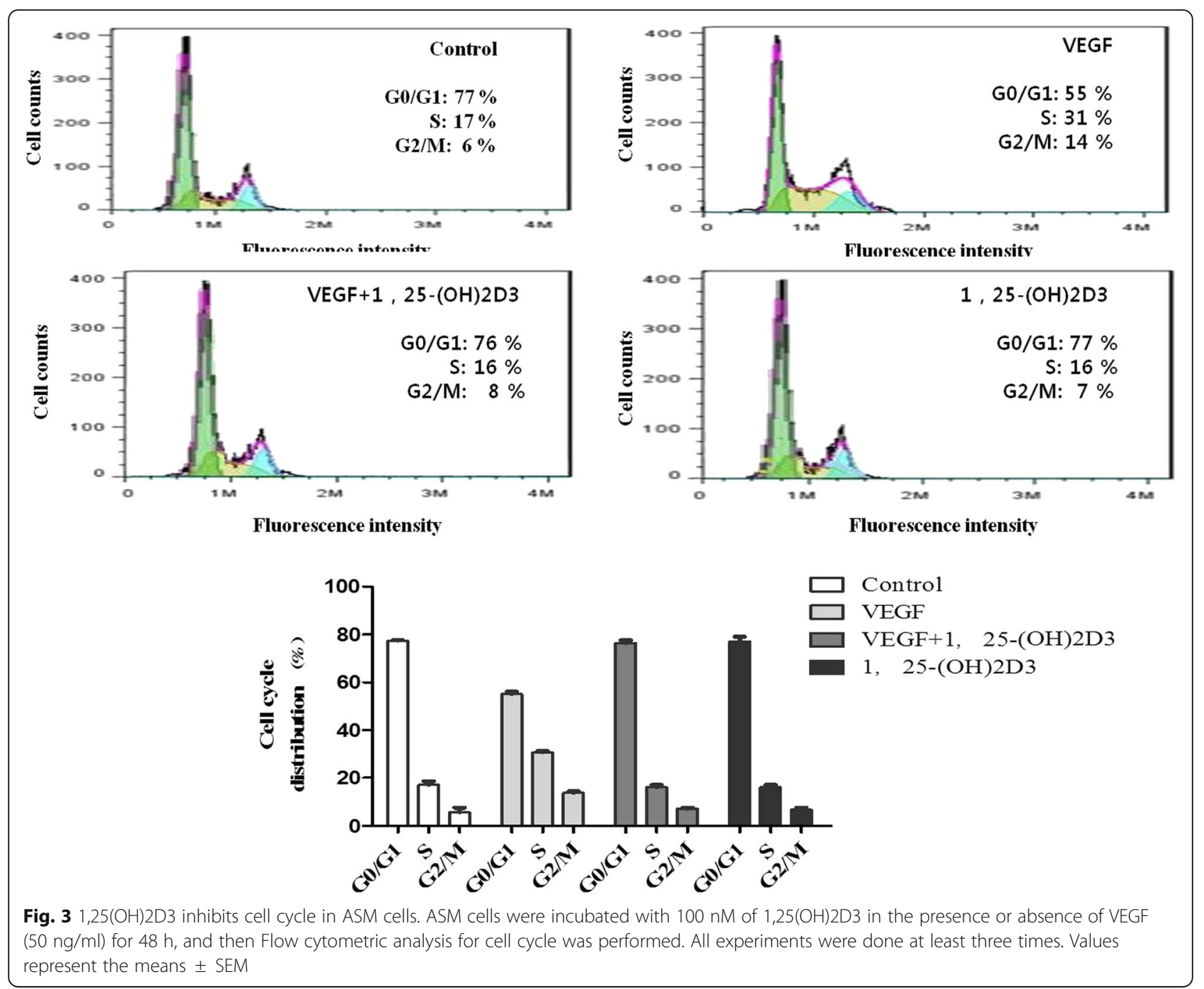

pathway for cytokine-stimulated, G-protein-coupledreceptor (GPCR)-mediated, or receptor tyrosine kinase (RTK)-mediated proliferation of ASM cells. It is known that the interaction of VEGF with VEGFR2 activates the MAPK/ERK1/2-dependent and PI3-k/Aktdependent signaling transduction pathways. In order to evaluate the effects of VEGF and 1,25- $(\mathrm{OH}) 2 \mathrm{D} 3$ on the activation of ERK1/2 and Akt in ASM cells, the levels of phosphorylated ERK1/2 and Akt expression were investigated by western blotting. When cells were incubated in the absence or presence of $50 \mathrm{ng} /$ $\mathrm{ml}$ VEGF for the indicated duration, an increase in the phosphorylation of ERK1/2 and Akt was observed, with no effect on the total levels of these proteins (Fig. 5a and b). In addition, treatment with 1,25(OH)2D3 significantly attenuated VEGF-stimulated ERK1/2 and Akt phosphorylation in a dose-dependent manner (Fig. 4c and d). The levels of phospho-ERK1/2 and phospho-Akt were not affected in 1,25-(OH)2D3- treated cells compared with the group without VEGF challenge.

In order to determine the signaling pathways that play a role in VEGF-induced ADAM33 expression and ASM cell proliferation, we used specific inhibitors of ERK1/2 and Akt signaling pathways. The inhibitors tested included U0126 (a MAPK/ERK1/2 inhibitor) and LY294002 (a PI3K inhibitor). Pretreatment of ASM cells with U0126 was found to significantly decrease ADAM33 expression in VEGF-treated ASM cells relative to control (Fig. 5e). However, VEGF-induced ADAM33 expression was not affected by the addition of LY294002 (Fig. 5e). These results demonstrate that VEGF increases ADAM33 expression through the activation of ERK1/2. We additionally investigated whether U0126 and LY294002 inhibit the VEGF-induced proliferation of ASM cells; when cells were incubated with U0126 or LY294002in the presence of VEGF, U0126 blocked VEGF-induced BrdU incorporation (Fig. 5f). However, LY294002 had no 

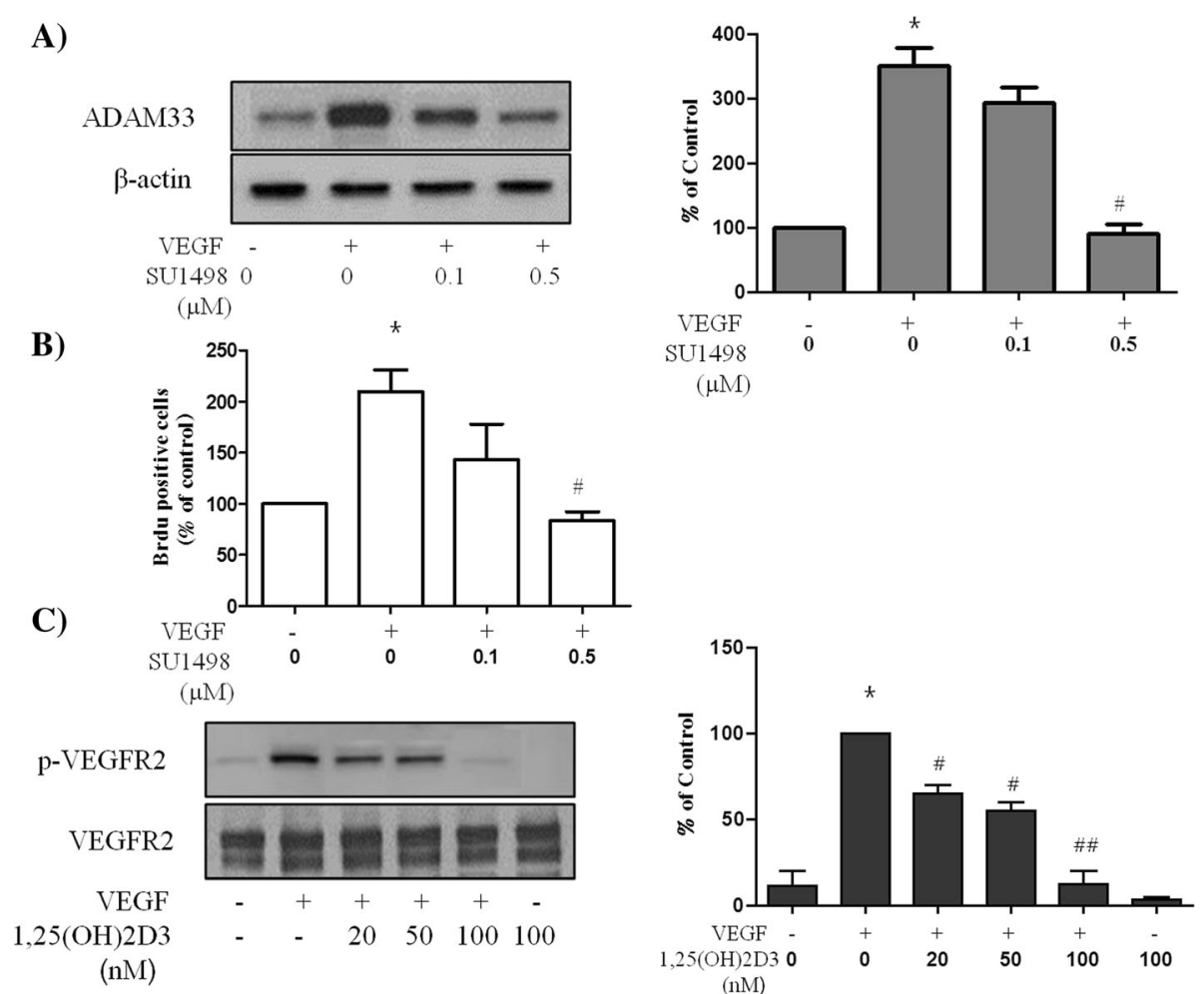

Fig. 4 1,25(OH)2D3 inhibits VEGF-induced ADAM33 expression and cell proliferation by inactivation of VEGFR2. ASM cells were incubated with indicated doses of SU1498 for $2 \mathrm{~h}$ before treatment with VEGF $(50 \mathrm{ng} / \mathrm{ml})$ for $24 \mathrm{~h}$, and then western blotting analysis for ADAM33 was performed. $\beta$-actin was used as a loading control (a). ASM cells were incubated with indicated doses of SU1498 for $2 \mathrm{~h}$ before treatment with VEGF (50 ng/ml) for $48 \mathrm{~h}$, and then cell proliferation was determined by BrdU incorporation (b). ASM cells were incubated with various doses of 1,25(OH)2D3 for 24 $\mathrm{h}$ before treatment or not with $50 \mathrm{ng} / \mathrm{ml}$ of VEGF for $30 \mathrm{~min}$, and then western blotting analysis for VEGFR2 was performed (c). All experiments were done at least three times. Values represent the means \pm SEM. ${ }^{*} P<0.05$ vs. control; ${ }^{\#} P<0.05,{ }^{\# \# ~} P<0.005$ vs. VEGF alone

effect on VEGF-induced BrdU incorporation (Fig. 5f). These data show that 1,25-(OH)2D3 inhibits VEGFinduced ADAM33 expression and proliferation of ASM cells through the suppression of the MAPK/ ERK1/2 pathway.

\section{Effect of 1,25-(OH)2D3 on VEGF secretion in ASM cells}

VEGF released from airway epithelial cells aggravates airway inflammation and remodeling. TGF- $\beta 1$ expression is elevated in asthmatic airways as well as in the bronchoalveolar lavage (BAL) fluid of patients with asthma. Therefore, we studied the effects of 1,25$(\mathrm{OH}) 2 \mathrm{D} 3$ on TGF- $\beta 1$-induced VEGF expression in ASM cells. The VEGF levels in culture supernatants from TGF- $\beta 1$-stimulated ASM cells were significantly higher than those in unstimulated cells (Fig. 6). However, 1,25$(\mathrm{OH}) 2 \mathrm{D} 3$ inhibited the release of VEGF from ASM cells stimulated with TGF- $\beta 1$ in a dose-dependent manner (Fig. 6). TGF- $\beta 1$ contributes to airway inflammation by enhancing VEGF release via the PI3-K pathway in human ASM cells. Therefore, these data suggest that 1,25$(\mathrm{OH}) 2 \mathrm{D} 3$ inhibits TGF- $\beta 1$-induced VEGF release, likely by attenuating Akt phosphorylation.

\section{Discussion}

Elucidating the regulatory mechanisms of human ASM cell proliferation has potential clinical value, and may provide further insights into new strategies for the treatment of airway diseases, such as asthma, associated with smooth muscle hyperplasia.

VEGF is a potent stimulator of angiogenesis in asthma. Studies have found that epithelial cell-secreted VEGF promotes airway remodeling in asthma [15]. In addition, VEGF levels are elevated in lung tissues and sputum of patients with asthma, and positively correlate with asthma disease severity. Furthermore, inhibition of VEGF leads to a significant reduction in goblet cell hyperplasia and basement membrane thickness [16, 17]. A previous study found that ASM cells under strain promote angiogenesis via secretion of VEGF, and that blocking VEGF attenuated these angiogenic changes [18]. In our previous study, we found that basal VEGF release from human ASM cells was comparable to that from BEAS-2B cells, a human lung epithelial cell line. VEGF secreted by ASM cells is thought to play a role in extracellular matrix modulation and fibronectin secretion, as well as in smooth muscle hypertrophy, and 


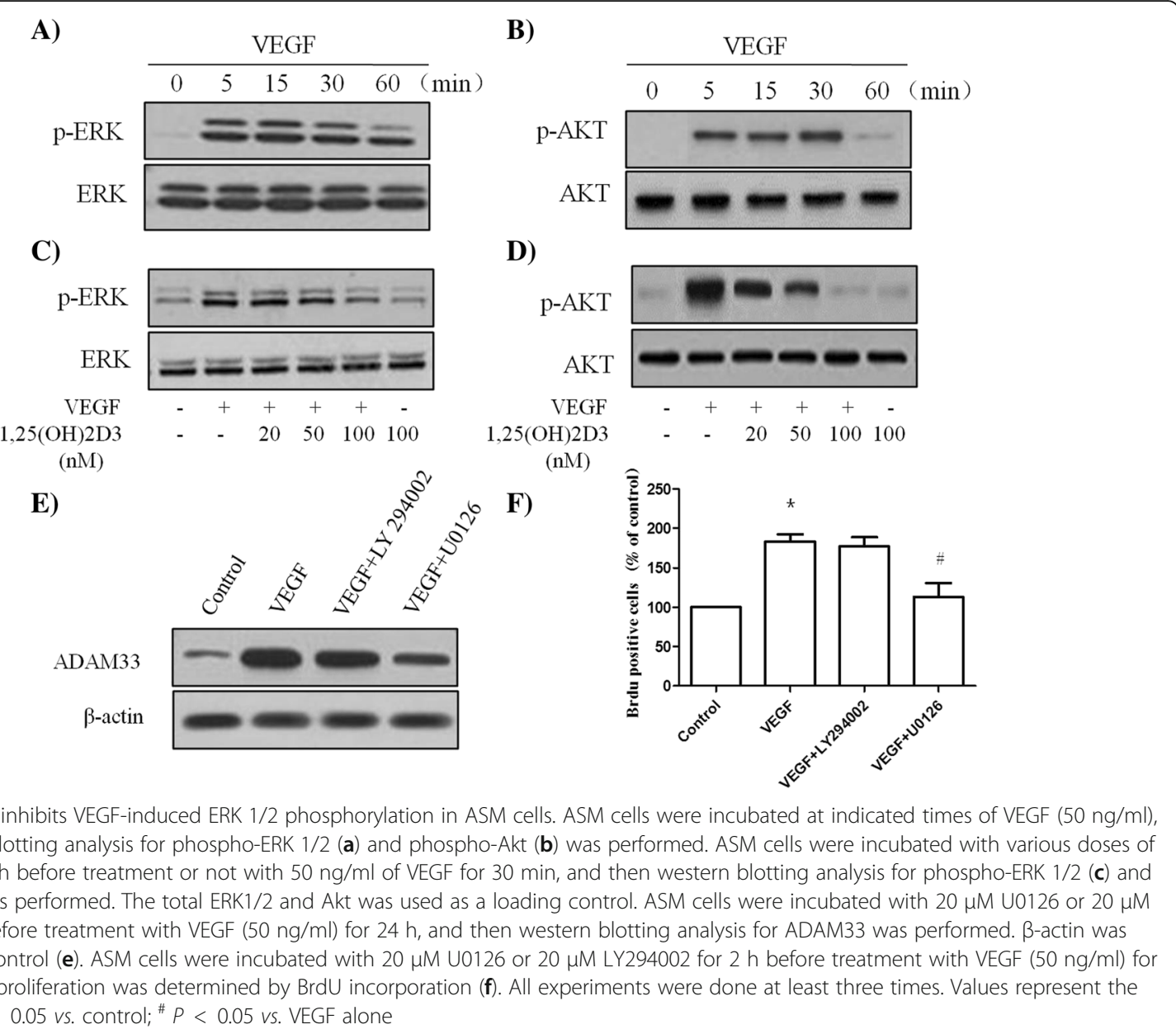

Fig. 5 1,25(OH)2D3 inhibits VEGF-induced ERK 1/2 phosphorylation in ASM cells. ASM cells were incubated at indicated times of VEGF (50 ng/ml), and then western blotting analysis for phospho-ERK $1 / 2$ (a) and phospho-Akt (b) was performed. ASM cells were incubated with various doses of 1,25(OH)2D3 for $24 \mathrm{~h}$ before treatment or not with $50 \mathrm{ng} / \mathrm{ml}$ of VEGF for $30 \mathrm{~min}$, and then western blotting analysis for phospho-ERK 1/2 (c) and phospho-Akt (d) was performed. The total ERK1/2 and Akt was used as a loading control. ASM cells were incubated with $20 \mu \mathrm{M} \cup 0126$ or $20 \mu \mathrm{M}$ LY294002 for $2 \mathrm{~h}$ before treatment with VEGF $(50 \mathrm{ng} / \mathrm{ml})$ for $24 \mathrm{~h}$, and then western blotting analysis for ADAM33 was performed. $\beta$-actin was used as a loading control (e). ASM cells were incubated with $20 \mu \mathrm{M}$ U0126 or $20 \mu \mathrm{M}$ LY294002 for $2 \mathrm{~h}$ before treatment with VEGF (50 ng/ml) for $48 \mathrm{~h}$, and then cell proliferation was determined by BrdU incorporation ( $\mathbf{f}$. All experiments were done at least three times. Values represent the means \pm SEM. ${ }^{*} P<0.05$ vs. control; ${ }^{\#} P<0.05$ vs. VEGF alone

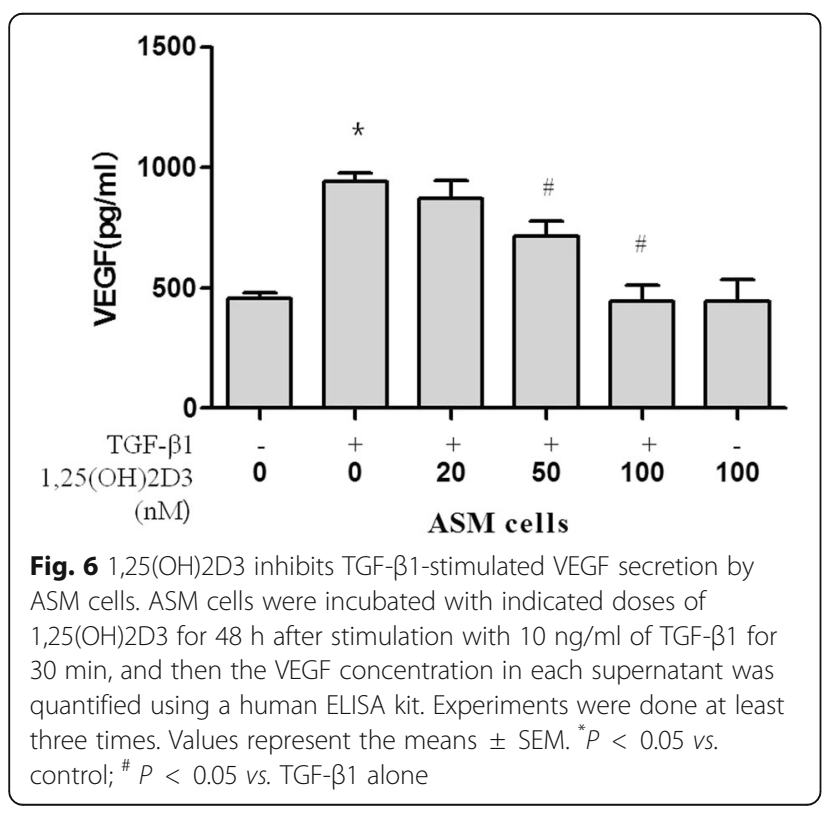

therefore in remodeling $[19,20]$. Therefore, in the present study, we investigated the effect of 1,25(OH)2D3 on VEGF-induced cell proliferation and relevant signal transduction pathways, as well as on TGF- $\beta 1$-induced VEGF secretion in human ASM cells.

ADAM33 was investigated as a potentially important molecule in ASM cell proliferation for a number of reasons. ADAM33 has been shown to be expressed in ASM cells and airway fibroblasts, suggesting a role for this gene in modifying cellular functions such as proliferation, migration, and differentiation [7, 9].

Indeed, ADAM33 expression was significantly higher in the airways of human subjects with asthma compared to those of controls. Further, increased expression correlated with asthma severity progression, from mild to severe lung function [21, 22]. As ADAM33 is predominantly expressed in ASM cells, Lin et al. investigated whether ADAM33 protein expression correlates with ASM cell mechanics in an ovalbumin- (OVA-) sensitized rat model; ADAM33 expression was found to be elevated in ASM cells from OVA-sensitized rats relative to non-sensitized rats. Importantly, ADAM33 expression positively correlated 
with cell traction force, stiffness, and expression of F-actin and vinculin, suggesting that ADAM33 is a mediator of ASM cell dysfunction in asthma [23]. Although the mechanisms for ADAM33-mediated remodeling are not clear, it has been reported that a soluble form of ADAM33 causes rapid induction of neovascularization both ex vivo and in vivo, as well as endothelial cell differentiation in vitro, suggesting that ADAM33 promotes angiogenesis and elicits airway remodeling [24]. Ito et al. investigated ADAM33 expression in ASM cells and found that ADAM33 mRNA and protein levels are significantly higher in these cells from subjects with asthma than in ASM cells from normal control subjects [9]. In this study, we demonstrated that 1,25(OH)2D3 inhibits VEGF-induced ADAM33 expression at both the mRNA and protein level, suggesting that expression may be primarily regulated at the mRNA level; however, it is necessary to study the ADAM33 promoter region as well as the transcription factors that putatively interact with this region in order to elucidate the pathways involved in the regulation of ADAM33 expression.

$1,25(\mathrm{OH}) 2 \mathrm{D} 3$ has been shown to inhibit the proliferation of airway smooth muscle cells [6]. Moreover, in utero vitamin D deficiency in mice leads to increased airway smooth muscle mass and airway resistance [25]. Furthermore, in children with severe asthma, lower levels of vitamin $\mathrm{D}$ have been shown to be associated with increased airway smooth muscle mass [26, 27]. Recently, $1,25(\mathrm{OH}) 2 \mathrm{D} 3$ has been reported to exert a negative regulatory effect on VEGF secretion $[5,28]$. The mechanism by which $1,25(\mathrm{OH}) 2 \mathrm{D} 3$ regulates VEGF secretion is currently unclear. However, several possible underlying mechanisms have been suggested such as the rapid induction of non-transcriptional responses, which may occur via activation of transmembrane signal transduction pathways, e.g. protein kinase $\mathrm{C}$, phosphatidylinositol 3-kinase/Akt, and p42/ p44 MAP kinase, all of which are closely associated with VEGF expression [5, 29]. In addition, it has been shown that 1,25(OH)2D3 induces rapid and sustained activation of phosphatidylinositol 3-kinase/Akt in a nongenomic manner [5]. Swain et al. reported that $1,25(\mathrm{OH}) 2 \mathrm{D} 3$ may regulate phopholipase $\mathrm{C}$ production by cells, which, in turn, may modulate signal transduction by receptors with tyrosine kinase activity, including VEGF $[5,30]$. Second, $1,25(\mathrm{OH}) 2 \mathrm{D} 3$ may modulate the expression of growth factor receptors [5, 31]. Finally, growth factors may modulate the expression of the nuclear vitamin D receptor [32]. Further studies are needed to elucidate the mechanisms by which $1,25(\mathrm{OH}) 2 \mathrm{D} 3 \mathrm{de}-$ creases VEGF secretion; this information should facilitate the development of new therapeutic strategies for the treatment of asthma.

It has been found that ERK1/2 activation is involved in cell growth, morphogenesis, and migration of endothelial cells stimulated by angiogenic factors [33, 34]. Moreover, the activation of PI3K/Akt is considered to play a role in a variety of biological functions such as cell growth, vascular remodeling, angiogenesis, and survival [34, 35]. VEGF promotes endothelial cell growth and survival via the ERK1/2 and PI3K/Akt pathways, respectively [36-38]. Walker et al. [39] compared the extent to which ERK1/2 or PI3K cascades contributed to $\alpha$ thrombin-stimulated or PDGF-stimulated proliferation of bovine tracheal smooth muscle, and found that, although the PI3K pathway was essential, the ERK1/2 pathway was required for a full mitogenic response. Such findings suggest that although active PI3K is sufficient for the stimulation of ASM DNA synthesis, either by GPCR-coupled or RTK-coupled pathways, parallel ERK1/2-dependent signaling events are required for maximal proliferation. Recent studies have shown that ERK1/2 activation, but not Akt activation, is required for HASM cell proliferation [40-42]. In the present study, we observed that ERK inhibition, but not PI3K inhibition, suppressed ADAM33 expression induced by VEGF. Further research is needed to elucidate the mechanism by which the ERK1/2 pathway enhances the transcription of ADAM33.

\section{Conclusion}

In conclusion, our results provide important insights into the mechanisms by which $1,25(\mathrm{OH}) 2 \mathrm{D} 3$ regulates VEGF-induced ADAM33 expression and ASM cell proliferation, as the effects of this compound on various underlying cellular signaling pathways such as the suppression of VEGFR2 and ERK1/2 phosphorylation. The present findings expand our knowledge of the role of $1,25(\mathrm{OH}) 2 \mathrm{D} 3$ in airway remodeling, and are expected to enable the development of effective therapies for airway diseases such as asthma.

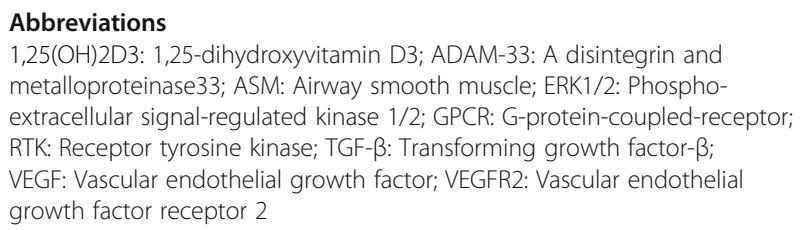

\section{Acknowledgements}

We acknowledge the facilities supported by the Central Laboratory of Tianjin First Central Hospital.

\section{Funding}

This work was supported by Science and Technology Fund of Tianjin Public Health Bureau (Grant No. 2015KR13).

Availability of data and material

Source data and material will be made available upon reasonable request.

\section{Authors' contributions}

Acquisition of data: QMP, MY, XJQ, and JBL Analysis and interpretation of data: SHK, PJ Drafting of manuscript: SHK. All authors read and approved the final manuscript. 


\section{Competing interests}

The authors declare that they have no competing interests.

\section{Consent for publication}

Not applicable.

\section{Ethics approval and consent to participate}

Not applicable.

\section{Author details}

'Department of Respiration, Tianjin First Central Hospital, Fukanglu-24, Nankaiqu, Tianjin 300192, China. ${ }^{2}$ Department of Radiology, Tianjin Hospital of Integrated Traditional Chinese and Western Medicine, Tianjin, China.

\section{Received: 2 October 2016 Accepted: 11 December 2016} Published online: 05 January 2017

\section{References}

1. Shin JH, Shim JW, Kim DS, Shim JY. TGF-beta effects on airway smooth muscle cell proliferation, VEGF release and signal transduction pathways. Respirology. 2009;14:347-53.

2. Kim SH, Yang M, Xu JG, Yu X, Qian XJ. Role of licochalcone a on thymic stromal lymphopoietin expression: implications for asthma. Exp Biol Med (Maywood). 2015;240:26-33.

3. Zou H, Xu YJ, Zhang ZX. Effect of vascular endothelial growth factor and its receptor KDR on human airway smooth muscle cells proliferation. Chin Med J (Engl). 2005;118:591-4.

4. Hirst SJ, Barnes PJ, Twort CH. PDGF isoform-induced proliferation and receptor expression in human cultured airway smooth muscle cells. Am J Physiol. 1996;270:L415-428.

5. Kim SH, Choi GS, Nam YH, Kim JH, Hur GY, Park SM, Park HS. Role of vitamin D-binding protein in isocyanate-induced occupational asthma. Exp Mol Med. 2012;44:319-29.

6. Damera G, Fogle HW, Lim P, Goncharova EA, Zhao H, Banerjee A, Tliba O, Krymskaya VP, Panettieri Jr RA. Vitamin D inhibits growth of human airway smooth muscle cells through growth factor-induced phosphorylation of retinoblastoma protein and checkpoint kinase 1. Br J Pharmacol. 2009;158:1429-41

7. Van Eerdewegh P, Little RD, Dupuis J, Del Mastro RG, Falls K, Simon J, Torrey $D$, Pandit S, McKenny J, Braunschweiger $K$, et al. Association of the ADAM33 gene with asthma and bronchial hyperresponsiveness. Nature. 2002;418:426-30.

8. Yoshinaka T, Nishii K, Yamada K, Sawada H, Nishiwaki E, Smith K, Yoshino K, Ishiguro $\mathrm{H}$, Higashiyama S. Identification and characterization of novel mouse and human ADAM33s with potential metalloprotease activity. Gene. 2002;282:227-36.

9. Ito I, Laporte JD, Fiset PO, Asai K, Yamauchi Y, Martin JG, Hamid Q. Downregulation of a disintegrin and metalloproteinase 33 by IFN-gamma in human airway smooth muscle cells. J Allergy Clin Immunol. 2007;119:89-97.

10. Song Y, Qi H, Wu C. Effect of 1,25-(OH)2D3 (a vitamin D analogue) on passively sensitized human airway smooth muscle cells. Respirology. 2007;12:486-94.

11. Song YF, Lai GX, Qi HW. Wu CG: [inhibition of 1,25-(OH)2D3 on passively sensitized human airway smooth muscle cells]. Zhonghua Jie He He Hu Xi Za Zhi. 2011;34:438-41.

12. Crane AM, Bhattacharya SK. The use of bromodeoxyuridine incorporation assays to assess corneal stem cell proliferation. Methods Mol Biol. 2013;1014:65-70.

13. Agrawal T, Gupta GK, Agrawal DK. Calcitriol decreases expression of importin alpha3 and attenuates RelA translocation in human bronchial smooth muscle cells. J Clin Immunol. 2012;32:1093-103.

14. Esteban MA, Wang T, Qin B, Yang J, Qin D, Cai J, Li W, Weng Z, Chen J, Ni S, et al. Vitamin $C$ enhances the generation of mouse and human induced pluripotent stem cells. Cell Stem Cell. 2010;6:71-9.

15. Lopez-Guisa JM, Powers C, File D, Cochrane E, Jimenez N, Debley JS. Airway epithelial cells from asthmatic children differentially express proremodeling factors. J Allergy Clin Immunol. 2012;129:990-7. e996.

16. Chetta A, Zanini A, Foresi A, D'lppolito R, Tipa A, Castagnaro A, Baraldo S, Neri M, Saetta M, Olivieri D. Vascular endothelial growth factor up-regulation and bronchial wall remodelling in asthma. Clin Exp Allergy. 2005;35:1437-42.

17. Yuksel H, Yilmaz O, Karaman M, Bagriyanik HA, Firinci F, Kiray M, Turkeli A, Karaman O. Role of vascular endothelial growth factor antagonism on airway remodeling in asthma. Ann Allergy Asthma Immunol. 2013;110:150-5.
18. Hasaneen NA, Zucker S, Lin RZ, Vaday GG, Panettieri RA, Foda HD. Angiogenesis is induced by airway smooth muscle strain. Am J Physiol Lung Cell Mol Physiol. 2007;293:L1059-1068.

19. Kazi AS, Lotfi S, Goncharova EA, Tliba O, Amrani Y, Krymskaya VP, Lazaar AL Vascular endothelial growth factor-induced secretion of fibronectin is ERK dependent. Am J Physiol Lung Cell Mol Physiol. 2004;286:L539-545.

20. Ribatti D, Puxeddu I, Crivellato E, Nico B, Vacca A, Levi-Schaffer F. Angiogenesis in asthma. Clin Exp Allergy. 2009;39:1815-21.

21. Lee JY, Park SW, Chang HK, Kim HY, Rhim T, Lee JH, Jang AS, Koh ES, Park CS. A disintegrin and metalloproteinase 33 protein in patients with asthma: relevance to airflow limitation. Am J Respir Crit Care Med. 2006;173:729-35.

22. Foley SC, Mogas AK, Olivenstein R, Fiset PO, Chakir J, Bourbeau J, Ernst P, Lemiere C, Martin JG, Hamid Q. Increased expression of ADAM33 and ADAM8 with disease progression in asthma. J Allergy Clin Immunol. 2007;119:863-71.

23. Lin F, Song A, Wu J, Jiang X, Long J, Chen J, Duan Y, Shi Y, Deng L. ADAM33 protein expression and the mechanics of airway smooth muscle cells are highly correlated in ovalbumin-sensitized rats. Mol Med Rep. 2013;8:1209-15.

24. Puxeddu I, Pang YY, Harvey A, Haitchi HM, Nicholas B, Yoshisue H, Ribatti D, Clough $\mathrm{G}$, Powell RM, Murphy $\mathrm{G}$, et al. The soluble form of a disintegrin and metalloprotease 33 promotes angiogenesis: implications for airway remodeling in asthma. J Allergy Clin Immunol. 2008;121:1400-6. 1406 e1401-1404.

25. Foong RE, Bosco A, Jones AC, Gout A, Gorman S, Hart PH, Zosky GR. The effects of in utero vitamin D deficiency on airway smooth muscle mass and lung function. Am J Respir Cell Mol Biol. 2015;53:664-75.

26. Gupta A, Sjoukes A, Richards D, Banya W, Hawrylowicz C, Bush A, Saglani S. Relationship between serum vitamin $D$, disease severity, and airway remodeling in children with asthma. Am J Respir Crit Care Med. 2011;184:1342-9.

27. Mann EH, Chambers ES, Chen YH, Richards DF, Hawrylowicz CM. 1alpha, 25-dihydroxyvitamin D3 acts via transforming growth factor-beta to up-regulate expression of immunosuppressive CD73 on human CD4+ Foxp3- T cells. Immunology. 2015;146:423-31.

28. Nakagawa K, Kawaura A, Kato S, Takeda E, Okano T. 1 alpha,25dihydroxyvitamin D (3) is a preventive factor in the metastasis of lung cancer. Carcinogenesis. 2005;26:429-40.

29. Ma Y, Yu WD, Kong RX, Trump DL, Johnson CS. Role of nongenomic activation of phosphatidylinositol 3-kinase/Akt and mitogen-activated protein kinase/extracellular signal-regulated kinase kinase/extracellular signal-regulated kinase 1/2 pathways in 1,25D3-mediated apoptosis in squamous cell carcinoma cells. Cancer Res. 2006;66:8131-8.

30. Swain LD, Schwartz Z, Boyan BD. 1,25-(OH)2D3 and 24,25-(OH)2D3 regulation of arachidonic acid turnover in chondrocyte cultures is cell maturation-specific and may involve direct effects on phospholipase A2. Biochim Biophys Acta. 1992;1136:45-51.

31. Koga M, Eisman JA, Sutherland RL. Regulation of epidermal growth factor receptor levels by 1,25-dihydroxyvitamin D3 in human breast cancer cells. Cancer Res. 1988;48:2734-9.

32. Haussler MR, Whitfield GK, Haussler CA, Hsieh JC, Thompson PD, Selznick SH, Dominguez $C E$, Jurutka PW. The nuclear vitamin D receptor: biological and molecular regulatory properties revealed. J Bone Miner Res. 1998;13:325-49.

33. Lee SJ, Namkoong S, Kim YM, Kim CK, Lee H, Ha KS, Chung HT, Kwon YG. Fractalkine stimulates angiogenesis by activating the Raf-1/MEK/ERK- and PI3K/Akt/eNOS-dependent signal pathways. Am J Physiol Heart Circ Physiol. 2006:291:H2836-2846.

34. Chung BH, Kim JD, Kim CK, Kim JH, Won MH, Lee HS, Dong MS, Ha KS, Kwon YG, Kim YM. Icariin stimulates angiogenesis by activating the MEK/ ERK- and PI3K/Akt/eNOS-dependent signal pathways in human endothelial cells. Biochem Biophys Res Commun. 2008;376:404-8.

35. Somanath PR, Razorenova OV, Chen J, Byzova TV. Akt1 in endothelial cell and angiogenesis. Cell Cycle. 2006;5:512-8.

36. Matsumoto T, Mugishima H. Signal transduction via vascular endothelial growth factor (VEGF) receptors and their roles in atherogenesis. J Atheroscler Thromb. 2006;13:130-5.

37. Kowanetz M, Ferrara N. Vascular endothelial growth factor signaling pathways: therapeutic perspective. Clin Cancer Res. 2006;12:5018-22.

38. Olsson AK, Dimberg A, Kreuger J, Claesson-Welsh L. VEGF receptor signalling - in control of vascular function. Nat Rev Mol Cell Biol. 2006;7:359-71.

39. Walker TR, Moore SM, Lawson MF, Panettieri Jr RA, Chilvers ER. Plateletderived growth factor-BB and thrombin activate phosphoinositide 3-kinase and protein kinase B: role in mediating airway smooth muscle proliferation. Mol Pharmacol. 1998;54:1007-15. 
40. Liao G, Panettieri RA, Tang DD. MicroRNA-203 negatively regulates c-Abl, ERK1/2 phosphorylation, and proliferation in smooth muscle cells. Physiol Rep. 2015;3.

41. Jia L, Wang R, Tang DD. Abl regulates smooth muscle cell proliferation by modulating actin dynamics and ERK1/2 activation. Am J Physiol Cell Physiol. 2012;302:C1026-1034.

42. Tang DD. Critical role of actin-associated proteins in smooth muscle contraction, cell proliferation, airway hyperresponsiveness and airway remodeling. Respir Res. 2015;16:134.

Submit your next manuscript to BioMed Central and we will help you at every step:

- We accept pre-submission inquiries

- Our selector tool helps you to find the most relevant journal

- We provide round the clock customer support

- Convenient online submission

- Thorough peer review

- Inclusion in PubMed and all major indexing services

- Maximum visibility for your research

Submit your manuscript at www.biomedcentral.com/submit 